\title{
Fremmede okseopkøbere i Danmark i 1508
}

\section{Af $H$. $V$. Gregersen}

Et regnskab over opkøb af okser i Danmark i 1508 hører til sjældenhederne. H. V. Gregersen meddeler og kommenterer et sådant, der findes udgivet i et tysk handelshistorisk tidsskrift. Det er ud over det handelshistoriske af stor betydning, fordi det også bringer en hidtil ukendt oplysning til dansk administrationshistorie.

De kilder, der foreligger til oksehandelens ældre historie, er overordentligt sparsomme, og det er derfor glædeligt, når nyt materiale dukker op. Et sådant foreligger ganske vist allerede siden 1973, trykt i Scripta Mercaturae (München) i form af en afhandling af dr. Ekkehard Westermann med titlen Register vom Ochsen- und Schweinekauf des Kasseler und Marburger Hofes in Dänemark, Hannover, Greven, Lipling, Buttstädt, Zerbst und Berlin von 1508-1618.

Et meget vigtigt bidrag til belysning af oksehandelens hverdag er denne afhandlings ældste kildeudgivelse, nemlig offentliggørelsen af et regnskab over okseopkøb i Danmark, som hoffet i Kassel i Hessen i 1508 lod foretage af Peter Rustemeister og Johann Widelbach, et par særligt befuldmægtigede ved hoffet. Efter udførelsen af deres mission har de to herrer udarbejdet et nøje register over alle de udgifter, som de havde haft på deres rejse til og fra kongens København for at skaffe sig toldfrihed for og tilladelse til opkøb af okser, der skulle bruges til hoffets underhold i Kassel.

Den 14. maj 1508, på Jubilate søndag, sendte den hessiske kammermester Georg Nussbicker de to udsendinge, Peter Rustemeister og renteskriver Johann Widelbach af sted, udstyret med en pengesum på 800 gylden. Vejen gik over (Hannoversch) Münden, derfra videre ned ad Weser-floden forbi Höxter og Hameln til Minden, indtil de - med nøje regnskab over kost og fortæring undervejs $\mathrm{i}$ form af brød og øl - den 19. maj nåede til Bremen. Over Bremervörde gik rejsen videre til Stade, hvorfra en færge førte dem til Hamburg.

Her blev de i to dage, fra søndag til tirsdag (21/5-23/5). De skulle nemlig se sig om efter karle til deres medhjælp. En af dem var »der 
schele Hans« (den skeløjede Hans). Han skulle gøre rejsen med helt til København, fordi han kunne dansk, og derfor måtte han straks have 2 gylden udbetalt.

Fra Hamburg af regnede de med lybske skillinger, 24 sk. pr. gylden, og det er i denne møntsort, regnskabet fra nu af aflægges:

2 sk. for øl i Langenhorn tirsdag morgen (23/5), 2 sk. for brød og øl to mil videre fremme i Ülzburg, samt 6 sk. til en vognmand, der havde kørt dem hertil. Natten blev tilbragt i (Bad) Bramstedt og kostede $8 \frac{1}{2}$ sk. for de to herrer og deres fire karle. Dertil 8 sk. for en vogn til Neumünster og ydermere 9 sk. til kost og øl til »selvsyvende«, nemlig til dem selv, de fire karle og til vognmanden. Fra Neumünster bragte en ny vognmand dem til Rendsborg. Han kostede 9 sk. og overnatningen fra onsdag til torsdag (24/5-25/5) blev på 14 sk.

Derpå gik rejsen videre $\mathrm{i}$ retning af Slesvig, som de tilsyneladende kørte udenom, idet et ophold blev gjort i Ruhekroog ved landevejen øst for Lyrskov, hvor fortæringen blev på 1 sk. Kørselen til $7 \frac{1}{2}$ sk. sluttede i den anselige Hærvejs-kro, Stenderupå (Stenderupau). Næste morgen (26/5) gik det mod Flensborg. Kørselen kostede 2 sk., og til kost og øl i Flensborg fredag middag gik der yderligere 6 sk.

Strækningen fra Flensborg til Toldsted ved Hærvejen vest for Åbenrå, uden sammenligning den kendteste af Hærvejskroerne, kostede 8 sk. i vognmandsløn. Undervejs nævnes en fortæring på 1 sk. i en kro, antagelig i Paulskro mellem Kliplev og Uge. Opholdet i Toldsted fra fredag til lørdag (26/5-27/5) kom til at koste 9 sk.

I løbet af lørdagen gik rejsen videre til Haderslev, hvor opholdet varede til mandag (29/5). Det kostede de seks rejsende 13 sk. "an moltyden« (til måltider), men dertil 6 sk. til øl. Man har formodentlig taget sig et lille hvil i hertugdømmernes nordligste by!

Om mandagen delte selskabet sig. Rustemeister rejste med tre af de fire karle »uber den sundt«, altså over Lillebælt, til Assens. Færgemanden kostede 9 sk. Der var tre mil, siges det, d.v.s. regnet fra Haderslev til Assens. Kort efter sendtes to af karlene tilbage til Haderslev for at hente de tilbageblevne, og derefter gik rejsen for alle seks over Fyn og Sjælland.

Atter engang skiftede møntfoden. 1 sk. var i kongeriget lig 3 hvid (witten), og der gik fyrre på 1 gylden. Udgifterne fra sted til sted skal dog i det følgende ikke refereres, kun rejseruten: tirsdag (30/5) Odense, derefter videre til Nyborg, hvor Storebælt passeredes (13 sk. til færgemanden), og i løbet af tirsdag nat nåedes Korsør. Onsdag morgen (31/ 5) fortsattes til Slagelse og til Roskilde, hvor der overnattedes. 
Endelig om torsdagen, Kristi Himmelfartsdag den 1. juni, havde de to okseopkøbere fra Kassel nået målet, kongens København, og de blev allerede om lørdagen (3/6) modtaget af kong Hans. Audiensen gav, hvad de fremmede havde ønsket, nemlig aftaler om okseopkøb og kongelig breve om toldfrihed. Først 3. pinsedag den 13. juni var selskabet rede til at tiltræde tilbagerejsen.

Den forløbne uges tid var bl.a. blevet anvendt til at skaffe sig de lovede breve i udfærdiget stand på dansk såvel som på tysk; men uden omkostninger fik de dem ikke! Regnskabet oplyser, at brevene kostede 2 gylden, nemlig 1 gylden til kongens tyske og 1 gylden til hans danske kancelli (»Item $2 \mathrm{fl}$ [orin] in die Cantzlei geschenkt, eynen in die tutsche und eyn in die denschen Cantzley des konnings vor eyn tutschen und denschen brif«).

Denne oplysning fra et regnskab, udarbejdet af et par hessiske okseopkøbere er af overordentlig stor betydning, idet man hidtil ikke har vidst, at der allerede i 1508 eksisterede et kongeligt tysk kancelli og et kongeligt dansk kancelli. I »Vejledende Arkivregistraturer, VII: Tyske Kancelli I (1946), skriver udgiveren, Johanne Skovgaard, i indledningen (s. XIV): »Et kongeligt tysk Kancelli findes forst fra Frederik Is Tronbestigelse, ledet af en særlig tysk Kansler, Wolfgang v. Utenhof«, og alle hidtidige behandlinger af Danmarks, Sønderjyllands og/eller Slesvig-Holstens historie hviler på den opfattelse, at Tyske Kancelli først blev dannet, da Frederik 1. i 1523 lod sit hidtidige hertugelige kancelli på Gottorp fortsætte som Tyske Kancelli i København. Denne opfattelse må nu efter kendskabet til det hessiske regnskab revideres, og det tør antages, at Tyske Kancelli i kongens hovedstad har været en naturlig følge af Christian 1.'s valg til herre over landene Slesvig og Holsten i Ribe i 1460. Fra da af har det været nødvendigt for kongen at have et særligt kontor til at udfærdige skrivelser på tysk.

Tilbage til okseopkøberne fra det fremmede, hvis Københavns-ophold kostede dem 1 gylden for kost og logis, samt 1 gylden 1 ort til $ø l$, bl.a. til kongens tjenere (utvivlsomt kancelliskriverne), der opsøgte dem i deres herberge, og i drikkepenge fik herbergets personale (»hussgesynde«) 4 sk.

Afrejsen foregik som nævnt 3. pinsedag den 13. juni; men selskabet nåede denne dag kun til Roskilde, hvor det blev natten over. Den følgende dag (14/6) fortsatte kørselen til Slagelse med et middagsophold undervejs i Ringsted. Torsdag morgen nåedes Korsør. Derfra gik det over Storebælt (10 sk., 2 hvid) med efterfølgende overnatning i Nyborg. Fredag formiddag nåede selskabet Odense; men dagsrejsen 
sluttede først på herregården Rugård vest-nordvest for Odense. Her havde okseopkøberne i København fået opgivet Tilluf Eriksøn Bjørn (hern Detleff von Erixsse) som en, der havde okser til salg, og hos ham havde de selvfølgelig gratis logis og kost. Næste dag gik det til Assens, hvorfra overfarten denne gang kostede 16 sk. (lig 1 mark dansk). Ankommen til hertugdømmerne havde man igen lybsk møntfod.

I Haderslev blev der holdt rast fra lørdag til mandag, men tirsdag (20/6) tog Rustemeister af sted for at forestå opkøbet af de eftertragtede okser, dels i Kolding og Middelfart, dels igen på Rugård og i Odense, hvor wher Detleff « opholdt sig.

I ugens løb lykkedes det ham at få købt 71 okser. Foruden de sædvanlige udgifter til logis, kost og øl (samt også »en flaske« til karlene til $4 \frac{1}{2} \mathrm{sk}$.) anføres $6 \mathrm{sk}$. til tyendet på Rugård, $6 \mathrm{sk}$. til to karle, der drev dyrene fra Rugård til Middelfart, samt 18 sk. til skipperen, der skulle færge okserne over Lillebælt. Andre to karle, der forestod drivningen frem til Kolding, fik 8 sk., og drivningen fra Kolding til Haderslev kostede $7 \mathrm{sk}$. Undervejs var 2 okser forsvundet $i$ en skov, og en karl, der forgæves søgte efter dem, fik ydermere $8 \frac{1}{2}$ sk. for sin ulejlighed.

I Kolding nød de to hessiske udsendinge for første gang gavn af den bevilgede kongelige toldfrihed; men tolderen var desværre ikke hjemme, så de måtte efterlade deres privilegiebrev hos borgmesteren, og det kostede dem senere $6 \mathrm{sk}$. at lade et bud afhente det i Kolding, mens de opholdt sig i Haderslev. En karl, der havde hjulpet med drivningen fra Kolding til Haderslev, kostede 3 sk. Til forskellige udgifter til de fire karle og dertil undertiden til to ekstra oksedrivere, samt til sig selv gennem hele fire uger, beregnedes 4 gylden, hvortil endnu kom $1 \frac{1}{2}$ gylden 1 ort til øl.

Mandag morgen (3/7) kunne renteskriver Johann Widelbach omsider ride oksedriften fra Fyn i møde, og gensynet med Rustemeister og med karlene fejredes i en kro mellem Kolding og Haderslev (antagelig Tømmeshus, nu Thomashus). Fortæringen her, brød og øl, blev på 2 sk. Da karlene lå med okserne uden for Haderslev (»vor Hadersleben«) blev udgiften til brød og øl $2 \frac{1}{2}$ sk. og dertil 2 sk. til karlene for øl i nattens løb.

Haderslev hørte siden 1490 under hertug »Friedrich von Hollstein etc.«, den senere Frederik 1., der netop i de dage opholdt sig på Haderslevhus. Men da de to hessiske udsendinge viste ham de kongelige fribreve, "was ers nicht wol fredelich«, og de måtte love fra det hessiske kancelli i Kassel at fremskaffe en bønskrivelse til hertugen om 
opnåelse af toldfrihed ved de hertugelige toldsteder. På den betingelse fik de lov til at passere Haderslev toldsted wsonder zoll«. - I en nøddeskal har man her hertugens iver for at blive anerkendt som regerende fyrste på linje med sin kongelige broder!

Tirsdag morgen $(4 / 7)$ blev der bevilget $2 \frac{1}{2}$ sk. ekstra til karlene til ol; 8 sk. havde de fået til fortæring. Det gjaldt nemlig nu om at få de fynske okser drevet gennem Haderslevs hovedstrøg. Det synes netop at være sket en tidlig morgen, fordi en sådan færdsel gennem byens gader ikke har været uden problemer. Rustemeister kom da også til skade med sin hest og måtte have $2 \frac{1}{2}$ sk. til anskaffelse af et plaster.

Inden deres afsked med Haderslev købte de to hessiske udsendinge endnu 120 okser ( 6 »stige« a 20) af Haderslevs dengang kendte oksehandler, Jørgen Anckersen, antagelig en broder til hestehandleren, borgmester Claus Anckersen. Lidkøbet i form af "winkouffe« androg 7 sk. Da den sidste afregning med deres vært, Peter Schriber, havde fundet sted, 6 sk. til havre og andet foder til deres heste, kunne de med god samvittighed forlade Sønderjyllands nordligste by.

Ved kroen mellem Haderslev og Toldsted - det må givetvis være Immervad - traf de det bageste kobbel okser, vel de i Haderslev opkøbte, og til oksedriverne her gik der 4 sk. lybsk til brød, smør og øl. Det forreste kobbel, formentlig okserne fra Fyn, traf de længere sydpå, og driverne ved dette kobbel måtte nøjes med for 2 sk. øl og smør; brød havde de åbenbart ingen brug for.

På Toldsted overnattede de to udsendinge, Rustemeister og Widelbach, formedelst 4 sk. 2 hvid til kost, øl, havre og andet foder. Desuden måtte de her punge ud med 6 sk. 2 hvid til en karl, der havde påtaget sig at hjælpe med til at drive kvæget fra Haderslev til Stenderupå. Toldsted hørte på den tid sammen med Åbenrå amt under kongen, og de slap derfor for at betale told. Torsdag morgen (6/7) var begge kobler fremme ved Toldsted, og oksedriverne fik derfor her for 3 sk. øl.

På deres videre færd til hest mod Flensborg opkøbte hesserne 90 okser af en af Flensborgs kendte oksehandlere, Michael Risenberg, og der måtte derfor nu udbetales $\frac{1}{2}$ gylden til oksedriverne. I løbet af torsdagen nåede de til Bov (Buckirchen), hvor de i kroen brugte 2 sk. til kost og øl, samt 3 sk. for at få skoet heste.

Vel ankommet til Flensborg måtte de af med 6 sk. for måltider med øl, samt havre og andet til hestene, og fredag morgen (7/7) besigtigede de hos Michael Risenberg de tidligere omtalte okser. Flensborg hørte også under kongen, og de slap derfor for at betale told i Bov, der ellers androg 8 sk. for 100 okser. Takket være det kongelige fribrev fik de 
også undtagelsesvis lov til at drive kvæget ad brolægningen gennem Flensborg.

Karlene ved de tre oksedrifter, som altimens var undervejs mod Stenderupå, fik 9 sk. til øl, brød, smør, ost og sild, men de havde åbenbart haft besvær med at holde styr på dyrene, for Widelbach måtte til bønderne på denne strækning punge ud med $8 \mathrm{sk}$. i erstatning (»schadegeld«), fordi det var gået ud over bøndernes korn ud mod Hærvejen.

I Stenderupå måtte de to udsendinge betale ikke alene for sig selv, men også for deres to heste og for de $\mathrm{i}$ alt ti oksedrivere, som de nu havde i deres brød. Det blev sammenlagt $17 \mathrm{sk}$. og dertil lørdag morgen (8/7) 7 sk. i fetalje (vittalien, egtl. viktualier, fødevarer), som de fik med sig i flasker og sække.

Lørdag aften nåedes Gottorp, hvor hertug Friedrich af Holsten og Slesvig holdt hof. Atter engang forelagde de spørgsmålet om toldfrihed, ikke mindst fordi tolden her var på 8 gylden 8 sk. for 100 okser. Hans Nådes hofmester gentog utilfredsheden med, at hertugens frænde $\mathrm{i}$ Hessen (»oheme und swoger «) ikke havde ladet ansøge om toldfrihed, men efter et løfte om, at det snarest ville ske, fik de lov til at passere uden at betale told, ja blev endog indbudt til taffel ved hoffet. Oksedriverne i kroen ved Gottorp (formentlig Rødekro ved Hærvejen) fortærede altimens for 12 sk. og søndag morgen (9/7) for endnu 2 sk.

Den næste nat blev tilbragt $i$ kongens by Rendsborg med deraf følgende toldfrihed, skønt satsen her ligesom ved Gottorp var 8 gylden 8 sk. for 100 okser. Måltider, kød, brød, øl og ost fra søndag aften til mandag morgen (11/7) blev sammenlagt på 11 sk. 1 hvid og dertil 2 hvid i drikkepenge til krokarlen.

Opholdet i Neumünster (11/7) blev på 18 sk. til øl, brød og smør, samt havre til hestene. Rækkefølgen kunne tyde på, at vejret har været varmt! Desuden gik der 12 sk. til en side flæsk til oksedriverne, der formentlig har fourageret under åben himmel. Tirsdag middag (12/7) blev der holdt rast $\mathrm{i}(\mathrm{Bad})$ Bramstedt, og her brugtes 8 sk. til karle og heste for kost, brød, øl, havre og andet foder. I Ülzburg var prisen for det samme til hele selskabet 11 sk.

Undervejs mod Hamburg var Rustemeisters udgift til oksedriverne 10 sk., mens Widelbach red i forvejen for at forhandle med borgmesteren, åbenbart om, hvilken rute de skulle benytte gennem byen. Hele onsdagen (12/7) gik hertil, og borgmesterens karl fik 1 sk. 1 hvid i drikkepenge for at have vist vej til skriveren og skaffet dem et mærke, der fortalte, at kvæget ikke skulle til markeds. Også torsdag (13/7) gik 
til hvil, og opholdet i Hamburg kom til at koste $1 \frac{1}{2}$ gylden til overnatning, måltider, samt øl og fødevarer $\mathrm{i}$ form af kød, smør og ost til karlenes sække. Men endnu et par udgiftsposter knytter sig til Hamburg, nemlig 14 sk., som de hessiske udsendinge spenderede under forhandlingerne, samt 3 sk. til øl til oksedriverne, der med deres kobler holdt til på Bleiche, en lokalitet, som et par gadenavne i nærheden af Jungfernstieg ved Binnen-Alster endnu minder om.

Mens de store oksedrifter på vej mod Nordvesttyskland og Nederlandene gik vesten om Hamburg, nemlig til Wedel og derfra med færge over Elb-mundingen, gik hessernes rute østen om Hamburg, over Bergedorf, hvorfra de tre oksekobler med deres ledsagere fredag morgen (14/7) færgedes over Elben. Vi skal i det følgende nøjes med at skitsere den videre rejserute, der gik over Winsen an der Luhe, Munster i Lüneburger Heide, østen om Hannover og langs med floden Leine, derefter over det hessiske bjergparti Solling forbi Uslar til Kassel, hvortil de ankom den sidste dag $\mathrm{i}$ juli måned 1508. $2 \frac{1}{2}$ måned havde rejsen til København og okseopkøbene i Danmark således taget.

Hjemme i Kassel kunne omkostningerne gøres endeligt op. Først var der udgifterne til løn til oksedriverne. De blev på sammenlagt $28 \frac{1}{2}$ gylden 9 hvid. De fire danske oksedrivere, der var gået fra i Hamburg, havde fået 4 gylden 5 sk. og dertil 16 sk. til fire par nye sko. Andre udgifter gik til tyske oksedrivere, der overtog arbejdet fra Hamburg til Kassel, og også de fik til nye sko. "Store Conrad" fra Danmark var med på hele rejsen fra sit hjemland til Kassel, og hans løn var 3 gylden 1 ort. Også "Skeløjede Hans« var med på hele turen; hans løn blev 3 gylden, samt et par nye sko. Samme beløb gik til Bernhard, der ligeledes havde været med helt fra Danmark. De forskellige tyske toldmyndigheder var ikke så venlige som de danske, så i toldafgift måtte hesserne punge ud med i guldmønt $9 \frac{1}{2}$ gylden 10 sk. 1 lybsk 2 hvid og 11 mathiasgroschen.

Størst interesse har udgifterne til okseopkøbene, da sådanne altid savnes $\mathrm{i}$ det hjemlige toldregnskabsmateriale:

71 okser fra Rugård på Fyn var blevet erhvervet for 5 gylden pr. par. Det blev i alt 178 gylden, idet $\frac{1}{2}$ gylden blev givet med i købet.

120 okser, der købtes af Jørgen Anckersen fra Haderslev, kostede $5 \frac{1}{2}$ gylden $\frac{1}{2}$ ort pr. par, og det blev sammenlagt $337 \frac{1}{2}$ gylden.

86 okser, købt af Michael Risenberg fra Flensborg, gik for 5 gylden 1 
ort 2 sk. lybsk pr. par og endnu 4 okser for 4 gylden pr. par. Det blev for alle 90 okser 237 gylden $6 \frac{1}{2}$ hvid.

Det samlede okseopkøb beløb sig derefter til $752 \frac{1}{2}$ gylden $6 \frac{1}{2}$ hvid for 281 okser. Hjemvendt til Kassel var der imidlertid kun 279 okser med, og det skyldes formentligt, at de to okser, der var forsvundet $\mathrm{i}$ skovegnene mellem Kolding og Haderslev ikke var blevet fundet.

Som vi har set $\mathrm{i}$ det foregående, var der ustandseligt udgifter forbundet med den lange rejse. Når driverløn og told medregnes, blev de samlede udgifter på $\mathrm{i}$ alt 851 gylden 5 hvid. Det oprindeligt afsatte beløb på 800 gylden havde således ikke kunnet holde.

Et regnskab som det foreliggende har naturligvis overordentlig stor interesse for enhver, der beskæftiger sig med handelens historie i ældre tid, og det ikke alene, fordi det er fra en så tidlig periode af oksehandelens historie, men også, fordi det giver en række oplysninger om, hvorledes et okseopkøb blev organiseret, hvilke rejseruter, der benyttedes, samt et indtryk af alle de udgifter og besværligheder, der var forbundet med et sådant foretagende.

Der kan læses adskillige oplysninger ud af det foreliggende regnskab. Det ses, at priserne på okser kunne variere en del. Det siger sig selv, at okser, opkøbt på Fyn, må blive billigere end dem, der befinder sig på det jyske fastland; men selv her er der prisforskelle at notere. En oplysning, der også er værd at tage med, gælder "Skeløjede Hans«, der var med fra Hamburg, fordi han kunne dansk. Han fik dengang straks udbetalt 2 gylden og ved tilbagekomsten til Kassel yderligere 3 gylden. Det vil sige i alt 5 gylden for knap $2 \frac{1}{2}$ måneders arbejde som oksedriver. Vejen var blevet tilbagelagt til fods. Derfor skulle der nye sko til. Opkøberne derimod var til hest. Også med hensyn til sociale tilstande giver et regnskab som det foreliggende således et lille indblik!

Det skal tilføjes, at dr. Ekkehard Westermann i sin afhandling i "Scripta Mercaturiae" har udgivet endnu et regnskab, nemlig over et okseopkøb, som et par hessiske renteskrivere foretog i Danmark i 1545. Det er givet i lidt større sammendrag med hensyn til udgiftsposter, men er naturligvis ligeledes af stor interesse. 